\title{
Titel/Title: The OECD PISA Study as a Soft Power in Education? Lessons from Switzerland and the US
}

\author{
Autor*innen/Author(s): Tonia Bieber \\ Kerstin Martens \\ Veröffentlichungsversion/Published version: Postprint \\ Zeitschriftenartikel/Journal article
}

\section{Empfohlene Zitierung/Recommended citation:}

Bieber, Tonia/ Martens, Kerstin (2011): The OECD PISA Study as a Soft Power in Education? Lessons from Switzerland and the U.S.. In: European Journal of Education, Sonderband: Education in Europe - how effective are international initiatives?, 46 (1), 101-116.

Verfügbar unter/Available at:

(wenn vorhanden, bitte den DOI angeben/please provide the DOI if available)

This is the peer reviewed version of the following article: "The OECD PISA Study as a Soft Power in Education? Lessons from Switzerland and the US", which has been published in final form at [https://doi.org/10.1111/j.1465-3435.2010.01462.x]. This article may be used for non-commercial purposes in accordance with Wiley Terms and Conditions for Use of Self-Archived Versions.

Zusätzliche Informationen/Additional information:

The author can be contacted at: martensk@uni-bremen.de 


\title{
The OECD PISA Study as a Soft Power in Education? Lessons from Switzerland and the US
}

\author{
Tonia Bieber \& Kerstin Martens
}

\section{Introduction ${ }^{1}$}

Internationalisation is a recent phenomenon in education policy, a field traditionally regarded as the domain of nation-states (Goldthorpe, 1997, p. 1; Enders, 2004, p. 361; Furlong, 2005, p. 53). One of the most influential international organisations in education today is the Organisation for Economic Cooperation and Development (OECD) (Rinne, Hokka \& Kallo, 2004; Martens, 2007), particularly through its Programme for International Student Assessment (PISA) which measures the performance of students who have completed compulsory schooling and are about to enter the labour market (Lingard \& Grek, 2007, p. 14). Since 2000, PISA has been conducted every three years in all OECD countries and beyond to test scientific, reading, and mathematical literacy, and problem solving abilities (www.pisa.oecd.org). Its results show the influence of students' socio-economic backgrounds, even in industrial nations (Buschor, Gilomen \& McCluskey, 2003). Today, it is seen as an indicator of the performance and social integration ability of education systems (Zahner et al., 2002). To support participating countries in improving their education systems, OECD derived recommendations from best practice examples provided by the PISA results. These comprise factors that were positively correlated with student performance. National implementation of its recommendations, however, remains voluntary (OECD, 2009). In this article, we look at two countries which reacted differently to their PISA results: Switzerland and the US. Although Switzerland scored well, the study ushered in overdue reforms, such as the intercantonal concordat 'HarmoS' to harmonise core benchmark figures and ensure quality in education (Bieber, 2010a). In contrast, PISA has remained outside US public perception and political debate, although the US scored below OECD average (Martens, 2010). In light of this, three questions arise: which OECD recommendations are reflected in national education reforms?, How did OECD governance further this convergence towards its policy model? and, how did domestic institutional settings mediate these effects?

Drawing on approaches to convergence (Holzinger \& Knill, 2008, p. 30), we analyse how OECD impacts on national education policy by making it converge towards its international 'model'. This

\footnotetext{
${ }^{1}$ The research presented here is part of a project on International Education Politics conducted at the University of Bremen (www.sfb597.uni-bremen.de/pages/forProjektBeschreibung.php?SPRACHE=en\&ID=14) in the framework of the Collaborative Research Center 'Transformations of the State', funded by the German Research Foundation (DFG). We thank Alexander Akbik and Priya Fielding-Singh for their help in preparing this article.
} 
article contributes to filling the gap concerning the role of OECD as a promoter of convergence (Morgan, 2009; Martens \& Jakobi, 2010, p. 1) and of national players as both supporters and antagonists. Taking a dynamic perspective on multilevel policy-making, we study the complex interplay whereby international imperatives are translated into domestic policies. To identify causal processes between the independent variable and its outcome (George \& Bennett, 2005, p. 206; Hall, 2006, p. 24), we use process tracing, based on document analysis and interviews of experts ${ }^{2}$ (Froschauer \& Lueger, 2003).

Education policy is the stepchild of policy analysis (Cibulka, 1994, p. 105; Jakobi, Martens \& Wolf, 2009), especially regarding internationalisation (Criblez \& ( $\leftarrow$ p. 101) Osterwalder, 2004, p. 7). Most studies were conducted in educational sciences (Fthenakis, 2003) or sociology (Wolter \& Vellacott, 2002). Although OECD enjoys a high international reputation, it has remained surprisingly little explored (Martens \& Jakobi, 2010, p. 1). Research on the effects of its PISA study on national reforms in education policy-making is scarce (Martens \& Wolf, 2006, p. 147; as an exception, see Grek, 2009; Knodel et al., 2010). Until now, the causal mechanisms whereby OECD can influence national reform initiatives with its PISA study and which national factors may have a hindering or furthering effect have not been analysed in sufficient depth. For Switzerland, Criblez (2008b) showed the importance of internationalisation, particularly of PISA, to dynamise political reforms and institutions. Research on PISA effects on policies in the US is almost non-existent (as an exception, see Dobbins \& Martens, 2010).

We shall now present the theoretical framework for analysing how PISA triggered political reactions in Switzerland and the US. Building on this, we provide empirical illustrations of its effect on their education policies: we evaluate how far the domestic reforms reflect OECD recommendations and how the interplay of OECD's transnational governance and domestic constellations have influenced these reforms. To conclude, we compare results of the country cases and illustrate possible developments in their education policies.

\section{Theoretical Framework on the Causal Mechanisms of Voluntary Convergence in Education Policy}

Literature on policy convergence helps to analyse the governance mechanisms of international organisations. Through regional integration processes, research on this topic has emerged as an additional core area of internationalisation studies (Knill,Tosun \& Bauer, 2009, p. 520). The literature

\footnotetext{
230 experts in Switzerland were interviewed between March 2008 and March 2010. In the US, 12 interviews were conducted between July and September 2008.
} 
has discussed mechanisms that may produce convergence (Holzinger \& Knill, 2008, p. 30). Since the implementation of OECD recommendations is voluntary, we focus on those which cause 'voluntary convergence' (Sommerer et al., 2008, p. 185), i.e. transnational communication, regulatory competition, and independent problem solving (Table I). ${ }^{3}$

Table I. Mechanisms of Voluntary Policy Convergence

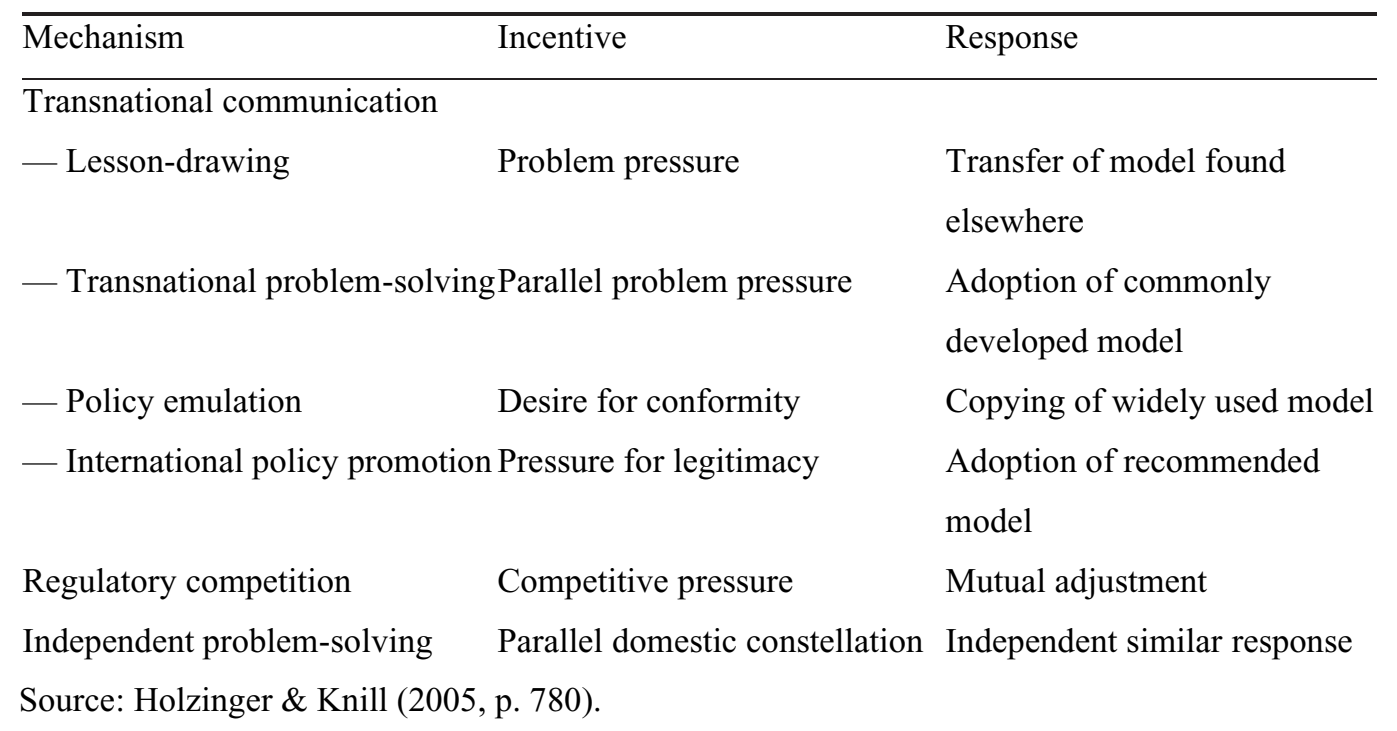

Transnational communication is most effective in producing convergence of structures, governance modes and policy styles in the context of soft governance (Knill \& Lenschow, 2005, p. 600). It refers to domestic actors' information exchange and $(\leftarrow \mathbf{p . ~ 1 0 2 )}$ communication in transnational expert networks which generate and spread ideas and change actors' beliefs and value systems (Knill \& Lehmkuhl, 1999) and comprise sub-mechanisms such as lesson-drawing, transnational problemsolving, policy emulation, and international policy promotion. These differ, but rely on communication across countries and international organisations (Holzinger \& Knill, 2008, p. 43). Hence, their distinction is more analytical than empirical.

'Lesson-drawing' refers to situations where national decision-makers draw on other countries' experiences or their own country's history to solve domestic problems (Rose, 1991; Meseguer Yebra, 2003). Thus, this type of learning is the result of a bilateral transfer. 'Transnational problem-solving' is another type of policy learning but is multilateral (Haas, 1992, p. 1; Knill \& Tosun, 2008, p. 515). Political and economic elites or epistemic communities (Haas, 1992) develop perceptions and solutions to similar domestic problems on the basis of shared scientific discourse cultures (Börzel \& Risse, 2002). 'Policy emulation' pertains to situations of high uncertainty in which policy-makers aim to increase their decisions' legitimacy (Gonon, 1998, p. 23; Tews et al., 2003, p. 594). Hence,

\footnotetext{
${ }^{3}$ These should be seen as complementary. Often, countries are subject to several of these mechanisms that also interact (Holzinger \& Knill, 2005, p. 777).
} 
they copy policies that are perceived to be successful or legitimate from states or international organisations with a positive reputation in the issue at stake (Bennett, 1991, p. 223; Barnett \& Finnemore, 2004; Mahon \& McBride, 2009). 'International policy promotion' refers to international organisations or countries that act as mediators. They spread best practice models via benchmarking and by evaluating domestic policy performance. Countries that rank low in international comparisons or do not follow the recommended models are under normative pressure to either legitimate their domestic models or adapt to these models (Knill \& Tosun, 2008, p. 515). In addition, international initiatives may further domestic adoption of their policy models by stimulating regulatory competition. This refers to the enhancement of the functional effectiveness of domestic institutional settings compared to other countries' achievements and involves related mutual adaptive reactions of the states concerned (Knill \& Lenschow, 2005, p. 585). The aim of reform is to shape regulatory exigencies so that the competitiveness of the national industry is maintained and emigration of capital and labour is hindered (Coleman, 2001; Holzinger \& Knill, 2005). For example, education is increasingly regarded as human capital and the wealth of nations (Nagel et al., 2010, p. 3). Hence, present developments show competitive features (Gürüz, 2003, pp. 21-24) in terms of contest for quality. Thus, a race to the top - the upward driving effects of policies to improve performance is more likely than a race to the bottom (Dobbins, 2008, 64; Knill \& Tosun, 2008, pp. 514-15). ${ }^{4}$ Countries compete for the best- performing system (Dobbins, 2008, pp. 63-64). They try to improve their education system's performance by meeting international recommendations.

Cross-national similarity of policies can also result from independent problem- solving, i.e. parallel, but independent reactions of domestic policy-makers to similar problem pressures. The higher the country-specific problem pressure, the more likely the convergence towards a recognised international model. Examples in education include demographic change, globalisation and marketisation (Kohlrausch \& Leuze, 2007; Walkenhorst, 2008).

\section{OECD Recommendations from PISA}

Convergence research deals with the 'tendency for policies to grow more alike, in terms of increasing similarity in structures, processes, and performances' (Drezner, $(\leftarrow$ p. 103) 2001, p. 53) and the consequential exhibition of characteristics and objectives that are shared by societies worldwide (Meyer, 2005). The approximation of domestic policies towards international policy models is associated with the concept of delta-convergence ${ }^{5}$ (Heichel et al., 2008, p. 83). In the two countries

\footnotetext{
${ }^{4}$ Usually, international regulatory competition is associated with a race to the bottom, which is the case in competition for prizes, for example.

${ }^{5}$ For other kinds of convergence see Heichel et al. (2008, pp. 81-83). The notion of convergence is often used for the approximation of policies of several countries (sigma-convergence).
} 
under study, we focus on policy output ${ }^{6}$ in terms of federal legislation (Holzinger \& Knill, 2008, p. 31; Holzinger et al., 2008, p. 563). OECD recommendations serve as a reference to assess policy convergence.

From the PISA results, OECD drew recommendations for secondary education policy-making (Table II). They concentrate on factors that were positively correlated with student performance in the PISA studies, though without claiming a causal relationship (OECD, 2009). They were made in international thematic reports in the aftermath of PISA. Ranging from rather implicit to very explicit statements, they provide a benchmark to measure the degree and dimensions of delta-convergence of domestic policies in secondary education towards the international models. On this basis, we analyse which of these recommendations have or have not been adopted in the countries under study and why.

\section{Table II. OECD Recommendations for Secondary Education Policy}

Equity

1. Social equity

2. Gender equity

\section{Structure and standards}

3. Cooperative school structure

4. Educational standards

\section{Quality assurance}

5. Teacher quality

6. Quality assurance

\section{Others}

7. School autonomy

8. Educational research and statistics

Source: own account, based on OECD (2004a; 2004b; 2009).

OECD's concept of education revolves around an economic rationale. PISA identifies eight core aims for countries to achieve in order to optimise their education systems. Equity is at the centre of its attention to the PISA study, as it has shown the negative effect of exclusion (OECD, 2009, p. 77). It is split into the dimensions of social (1) and gender equity (2). Moreover, OECD furthers reforms of national school structures (3) that turn selective models into integrated ones because selection and tracking constitute institutional barriers that reinforce socio-economic disparities (OECD, 2004b, p. 65). It suggests specifying educational standards (4) of quality (OECD, 2009, p. 14). Teacher training (5) receives special attention because an integrated school structure requires teachers to individually promote students from different backgrounds. OECD advocates furthering teachers' professional

\footnotetext{
${ }^{6}$ Other policy dimensions of convergence include outcomes, style, process, and content (Bennett, 1991, p. 418; Holzinger \& Knill, 2008, p. 35).
} 
development and education (OECD, 2009, pp. 25-26). It also supports more rigorous procedures for the selection of candidates at the beginning of teacher training to increase teachers' qualifications and social status (OECD, 2004b, pp. 65-66). In order to improve the competitiveness of public services, internal and external quality assurance systems of student performance (6) are recommended to identify difficulties, as monitoring student and system $(\leftarrow$ p. 104) performance standards is seen as key for the success of education systems (OECD, 2004a, p. 19). School autonomy (7) is regarded as suitable to improve school systems by delegating responsibilities to schools and local authorities (OECD, 2004a, p. 19; 2004b, p. 67, 71). This includes the liberty to choose course content, allocate budgets, and admit students. Educational research and statistics (8) should be improved to inform policy-making and practice, allowing them to draw on a broad knowledge database (OECD, 2009, p. 87). This meets the growing demand for evidence-based policy-making.

\section{Switzerland — PISA as a Catalyst for Harmonisation}

Switzerland is a political exception that is worth examining. Did OECD soft governance mechanisms evoke any response in this country, which is characterised by a myriad of veto players and a strong sense of political autonomy? We assess which OECD recommendations Swiss policies converged to and how.

\section{The 'HarmoS' Project and its Reference to OECD Recommendations}

The Swiss political system, which includes federalism ${ }^{7}$, direct democracy, consociationalism and subsidiarity (Scharpf, 1988; Hega, 2000), involves many veto players. This not only prolongs domestic decision-making, but also hinders cooperation with international organisations. Hence, a structural-conservative education policy entailed a backlog demand in light of international developments (Criblez, 2008b, p. 296). In the 1970s, great pressure for harmonisation developed because of incompatible cantonal school structures that caused mobility problems (Maradan \& Mangold, 2005, p. 3). However, reform efforts were hindered by the cantons and the Swiss people's party.

After the turn of the century, secondary education underwent far-reaching transformations. One resulted from the 2006 constitutional amendment that was accepted by $86 \%$ of the people and by all cantons. The new educational article $61 \mathrm{a}$ anchored the aim of developing a single national education

\footnotetext{
${ }^{7}$ Switzerland has 26 cantonal education systems. Yet one can speak of one single system because of intercantonal agreements.
} 
area in the Constitution. This laid the foundation for harmonising the 26 cantonal education systems (APRENTAS, 2006) and obliged the cantons, which are responsible for secondary education, to unitarily regulate important structural benchmark figures for the whole country. If they do not succeed, the new article 62 authorises the Federation to enact the directives required in these traditionally cantonal competence areas (Criblez, 2008b, p. 288). This paved the way for the most important political reform in recent decades. The 'intercantonal agreement on the harmonization of obligatory schooling', or 'HarmoS', is a school concordat which came into effect in 2009. So far, 15 cantons have joined and are bound to introduce necessary legal and structural adaptations by 20152016.

HarmoS aims at furthering the harmonisation of compulsory schooling in order to promote quality and permeability on an all-Swiss level and facilitate domestic mobility (EDK, 2009). Therefore, it involves comprehensive structural and content-related changes (Table III). These show a great influence of OECD recommendations that promote social integration and equity of chances. With HarmoS, the Swiss Conference of Cantonal Ministers of Education created the basis of a far-reaching national alignment of structural benchmark figures: the duration and aims of educational phases and their transitions. The national solutions in the 1970 school concordat concerning the benchmark figures of school entrance age and compulsory attendance were updated. The duration of $(\leftarrow \mathbf{p . ~ 1 0 5})$ compulsory school was prolonged from nine to eleven years so that entrance into kindergarten and basic school became obligatory at the age of four. Thus, to further social integration, HarmoS took into account the PISA finding that most high-performing school systems include early school enrolment (EDK, 2007).

Table III. Instruments of the Intercantonal Agreement on the Harmonisation of Compulsory Schooling

\begin{tabular}{|l|l|l|}
\hline $\mathbf{1 .}$ & $\begin{array}{l}\text { Subordinate aims of } \\
\text { obligatory schooling }\end{array}$ & $\begin{array}{l}\text { Basic education aims } \\
\text { Language teaching }\end{array}$ \\
\hline $\mathbf{2 .}$ & Structural benchmark figures & $\begin{array}{l}\text { School enrolment } \\
\text { Length of levels of education }\end{array}$ \\
\hline $\mathbf{3 .}$ & $\begin{array}{l}\text { Instruments of system development } \\
\text { and quality assurance }\end{array}$ & $\begin{array}{l}\text { Educational standards } \\
\text { Curricula, teaching aids and evaluation } \\
\text { instruments } \\
\text { Portfolios } \\
\text { Educational Monitoring }\end{array}$ \\
\hline 4. & Organisation of the school day & Core times and day structures \\
\hline
\end{tabular}

Source: own account, based on EDK (2007).

HarmoS pledged the cantons to comply with national education standards to be tested after the fourth, 
eighth, and eleventh year of the new count in five core areas ${ }^{8}$ of basic education. It also defined the procedure for their establishment so as to reduce diversity of cantonal school systems of the single education phases and assure quality (Zahner Rossier et al., 2005). The introduction of standards implied greater consideration of students' competences and signalled a different testing culture (Meyer-Hesemann, 2010) which involved a shift from an input-oriented rationale to a logic of steering directed towards efficiency and output control (Eckert, 2009, pp. 272-273; Schweizerische Koordinationsstelle für Bildungsforschung, 2010, p. 55). HarmoS was also the first attempt by the Federation and the Swiss Conference of Cantonal Ministers of Education to develop a national education evaluation and monitoring system (Maradan \& Mangold, 2005). Unlike in other countries, student performance and learning behaviour had not been regularly analysed until then. The evaluation and monitoring system rests on four-yearly reports that provide comparative and wideranging data on output and quality. The first report of 2010 judged the attainment of education standards and the performance of the system in efficiency, effectiveness, and equity (Schweizerische Koordinationsstelle für Bildungsforschung, 2010). The introduction of common standards and the promotion of an educational monitoring system match OECD recommendations on the establishment of education standards as well as research and statistics.

In sum, OECD's recommendation on social equity was strongly supported by HarmoS' structural reforms, such as the introduction of optional day care and core times (Table IV). The prolongation of the time spent together by pupils promoted the cooperative school structure. HarmoS established standards for particular subjects and education phases, as well as unitary curricula for linguistic regions. In order to inform education politics and practice, Switzerland introduced statistics for the purpose of regular monitoring. Reforms did not comprise the promotion of teaching quality or the establishment of quality assurance systems because they had already been implemented by reforms independent of PISA. But school autonomy and the promotion of gender equity were not addressed.

\section{$(\leftarrow$ p. 106)}

Table IV. Swiss Delta-Convergence towards PISA

\begin{tabular}{llc}
\hline & \multicolumn{1}{c}{ OECD Recommendations } & Swiss Convergence \\
\hline 1. & Social equity & $\mathrm{X}$ \\
2. & Gender equity & 0 \\
3. & Cooperative school structure & $\mathrm{X}$ \\
4. & Educational standards & $\mathrm{X}$ \\
5. & Teaching quality & $\mathrm{p}$ \\
6. & Quality assurance & $\mathrm{p}$ \\
7. & School autonomy & 0
\end{tabular}

\footnotetext{
${ }^{8}$ These comprise languages, mathematical and natural sciences, social sciences and humanities, music and arts, as well as sports and health.
} 
$\mathrm{X}=$ reforms due to OECD recommendations

$\mathrm{p}=$ previous fit of national policy and OECD recommendation

$0=$ no corresponding reforms

\section{International Driving Forces of Swiss Policy Convergence}

The aims of HarmoS were not new. Prior to PISA, efforts had been made to harmonise the cantonal school systems, as the 1970 school concordat did not suffice to enhance intra-Swiss mobility (Interview CH06). Following failed coordination attempts in the 1990s, the Swiss Conference of Cantonal Ministers of Education has, since 2001, focused on a legally binding intercantonal concordat (Maradan \& Mangold, 2005, p. 3; EDK, 2007).To increase European mobility, the National Council aimed to dissolve sectionalism and consider education as a federal competence (Interview CH06). The fear of federal intervention in the cantonal sphere of education, referred to as the 'sword of Damocles' (Interview CH15), motivated the cantons to accept an intercantonal concordat to face the domestic problem pressure. However, only the impetus from the international level pushed the concretisation of these reform efforts.

As Switzerland had never participated in the 'Progress in International Reading Literacy Study' and only once in the 'Third International Mathematics and Science Study' conducted by the International Association for the Evaluation of Educational Achievement in 1995, the PISA study provides the only internationally comparable and reliable data on student performance (Schweizerische Koordinationsstelle für Bildungsforschung, 2010). While it obtained comparatively good results in mathematics and natural sciences, PISA revealed unexpected shortcomings in reading competences, where a high percentage of 15-year-olds only just reached or even scored below the lowest competence level (Buschor et al., 2003). It showed that Switzerland was one of the OECD countries where the influence of students' socio-economic backgrounds on their reading skills was the most pronounced (OECD, 2002). It also revealed a high discrepancy between excellent and poor performance in all three competence areas, the dependency of proficiencies in mathematics and reading on gender, and the performance gap between linguistic regions.

Although often well above OECD average, the PISA scores did not meet national expectations, as the Swiss had regarded their system as the best in Europe. The influence of socio-economic background on student performance shocked the country of immigration. This propelled education to the top of the political agenda and increased reform pressures (Interview CH06). The governing parties drew similar conclusions from the PISA results, but stressed different aspects. Yet HarmoS was finally adopted, as PISA opened a 'window of opportunity' for reform protagonists seeking solutions to domestic problems. It provided a source of legitimisation of overdue reforms and thus enabled $(\leftarrow$ p. 107) necessary corrections in the education system (Bieber, 2010a). This increased 
the reform dynamics of education politics (Criblez, 2008a, pp. 280-81).

OECD was particularly apt for external legitimisation, as it is an expert organisation with approved scientific work (Interview CH10) and PISA is renowned in the Swiss education scene as a highly sophisticated study. Political actors referred to the international requirements proved by its results when introducing HarmoS (Buschor et al.; 2003). Concerning the innovation of early school enrolment, reformers pointed to PISA's evidence of high social discrimination (Interview CH07; SKBF, 2010, p. 54). Likewise, minimum standards intended to benefit the weakest students (EDK, 2004) were developed by referring to the recommendation of introducing education standards. Moreover, HarmoS' aim to improve language skills was explained by the PISA insight into the lack of reading competences (APRENTAS, 2006). Via PISA, OECD disseminated a performance culture and promoted an economic rationale that led to the partial adaptation of Swiss guiding principles to those of OECD. While education had been regarded as a civil right, OECD's economic ideas on education influenced the reform endeavours. Hence, the performance of the education system was from then on evaluated according to its benefit for the economy. Switzerland acknowledged that the economic growth of a country depended on the development of its education system, particularly in a comparatively highly industrialised country in great need of qualified labour (Interview CH05).

The dissemination of economic ideas and knowledge on PISA's transnational platform also enhanced the competition of the participating countries. PISA provided the Swiss school system with data on educational indicators which enabled it for the first time to compare its conditions and performance with other countries. This put competitive pressure on national policy-makers (Interview CH05, Parreira Do Amaral, 2006, p. 84), as economic growth promoted the education reform. Pressure to address the issues revealed by the PISA results was particularly strong, as one had expected better performance given its comparatively high education expenses (OECD, 2007, p. 72; OECD, 2010), the third highest of all PISA countries (Zahner et al., 2002, p. 51). To 'survive' in the competition for the best education system, reforms focused on OECD recommendations on the optimisation of national school systems that include international best practices, and thus on the highest standards in terms of a race to the top (OECD, 2004a; 2004b; 2009). This coined the contents of HarmoS.

In short, after a long phase of backlog, international developments gave the impetus for change. By providing a transnational platform for communication and enabling the contest of education systems, the PISA study played a vital role in the introduction of the latest secondary education reforms and in producing a high degree of delta-convergence of policies towards its recommendations.

\section{The US - No Echo to the PISA Study}

US education policy has been a field of continuous reforms, as the poor state of the level of education 
has long been known. But unlike in Switzerland, transnational communication and regulatory competition as promoted by PISA do not play a role. Despite its low performance in PISA, the OECD study is not an issue. Reforms are carried out independently of the results of international comparative surveys and policy learning. We assess if and in which areas there is consistency between the aims of US education policy and OECD recommendations. $(\leftarrow$ p. 108)

\section{Reforming US Education Independently of PISA}

The US has participated in all PISA surveys. Compared to the other participants, however, it is one of the countries in which student performance in the OECD's comparative study was least perceived. Although results have consistently been below the OECD average in all PISA surveys, American politics and the public paid very little attention to the study (Dobbins \& Martens, 2010). The national media response was the lowest of all OECD countries (Martens \& Niemann, 2010). Seen from the US perspective, PISA did not contribute any significant new information: as the low quality of many schools has long been common knowledge, problem pressure was not enhanced. PISA only confirmed knowledge of these shortcomings and did not provoke any strong reactions (Interview US01).

The education system has been under constant reform since the 1980s when the administration appointed a national commission to investigate its progress 25 years after the Sputnik shock. The final report in 1983, A Nation at Risk: Imperatives for Educational Reforms (National Commission on Excellence in Education, 1983), offered a sobering picture: the education system appeared in desolate condition. The report triggered widespread public unease over the quality of education and the need to inspect schools, standards, and teachers. These concerns culminated in the 'great school debate' (Gross \& Gross, 1985) in the following years. Education concerns were among the most important reform undertakings of any presidency. Viewed in this light, the US had already experienced its 'Bildungsshock' decades before other nations like Germany, Switzerland, or Mexico with the PISA study (Knodel et al., 2010). The shortcomings of the school system have become a disputed matter of fact, with the consistent implementation of many reform processes and new strategies. However, their success has been moderate, resulting in increasing disillusion (Interview US06; Interview US10). The current federal education act is the No Child Left Behind Act (NCLB) of 2002 which came into force under the Bush administration. It authorises several national programmes to improve the performance of primary and secondary schools by increasing the responsibilities of federal states vis-à-vis school districts and schools themselves. NCLB also grants parents more flexibility in school choice. It obliges federal states that apply for school sponsorship to establish assessment criteria that measure students' basic competences for the respective level of education. However, it avoids the creation of a national performance standard. Each federal state can, in accordance with the school autonomy principle, set its own standards. 
The debate on reforms under the Obama administration with the slogan 'Race to the Top' would make education more centralised and federally controlled. President Obama calls for a fundamental revision of NCLB and, although he did not suggest the establishment of a national curriculum, he did suggest the implementation of national standards. Also, the government would replace the school ratings system based on pass-fail by one that measures individual student progress and judgement of schools. The envisioned system relies on test results and on the use of indicators, such as the number of students skipping school, graduation rates, and learning environment. The proposal demands intervention in failed schools, but also reduces government intervention in well-administrated middleranking schools (Dillon \& Lewin, 2010). Obama's proposal includes funds for preschool programmes, merit pay for teachers and the creation of more charter schools. Table V shows how the education system corresponds to OECD $(\leftarrow \mathbf{p}$. 109) recommendations. Although equity has been an important issue since the 1960s, the current reforms do not provide measures to improve opportunities for children from migrant backgrounds or low economic situations, as recommended by OECD. Overall, the envisioned aims under NCLB and the Obama administration correspond to most OECD recommendations, but no reference to PISA is made (Interview US01; Interview US04).

Table V. US Delta-Convergence towards PISA

\begin{tabular}{llc}
\hline & \multicolumn{1}{c}{ OECD Recommendations } & Swiss Convergence \\
\hline 1. & Social equity & 0 \\
2. & Gender equity & 0 \\
3. & Cooperative school structure & $\mathrm{p}$ \\
4. & Educational standards & $\mathrm{p}$ \\
5. & Teaching quality & $\mathrm{p}$ \\
6. & Quality assurance & $\mathrm{p}$ \\
7. & School autonomy & $\mathrm{p}$ \\
8. & Educational research and statistics & $\mathrm{p}$ \\
\hline
\end{tabular}

$\mathrm{X}=$ reforms due to OECD recommendations

$\mathrm{p}=$ previous fit of national policy and OECD recommendation

$0=$ no corresponding reforms

\section{Obstacles to Incorporating International Impulses into the US Education System}

Part of the reason why PISA is not perceived in the US can be traced to its education system which can be defined as highly decentralised and heterogeneous. Education is locally organised as regards school structures and content. Institutionally, the American Government has very little say in the education realm; the US Constitution does not provide for any rights of the Federation in the field; this is delegated to state level. Before 1979, the Federal Ministry of Education did not exist. The 1965 Elementary and Secondary Education Act (ESEA) is considered the most important federal law in the education sector (United States Federal Statute, April 11, 1965). However, it mainly controls the 
Federation's expenditures for elementary and secondary schools.

A Nation at Risk led to the revitalisation of education policy issues at the national level, where the need to develop standards and evaluation criteria was the pivotal point. As a policy field, education was no longer exclusively managed by the local or constituent state government, but also became an issue of federal concern (Busemeyer, 2007, p. 78). Thus, since the 1980s, several reforms have been implemented to generate standards, clarify responsibilities, and offer free school choice and greater teaching quality. The conviction that the introduction of standards with measurable goals would bring about better individual education outcomes mainly led to an outcome-oriented education system.

NCLB is considered the national government's biggest augmentation in authority in education policy since ESEA and can almost be regarded as a revolution (McGuinn, 2006). However, this shift in authority can hardly be compared to the competences of governments in other countries where the questions of what content is taught and when are centrally regulated, as in France. Quite unusually, the NCLB was supported by both the Democrats and Republicans. The Democrats pushed through additional funding of schools and the Republicans brought about more transparent responsibilities and more freedom in school choice. NCLB will be renewed by the end of 2010 . $(\leftarrow$ p. 110) In brief, the education system corresponds to most of the recommended aims promoted by the PISA study. With NCLB, the US aimed to introduce more standardised goals for the whole country, which increased its resemblance with other educational systems. However, the school system has yet to improve. More- over, this education act and the envisioned reforms under the Obama administration have taken place independently of the PISA study. From a theoretical perspective of convergence approaches and their voluntary mechanisms, independent problemolving seems to prevail.

\section{Comparative Conclusion on the Impact of OECD Soft Governance on National Policies}

In the PISA context, OECD influence not only consists in identifying systemic weaknesses. From best practice examples of 'winner countries' such as Finland, it drew recommendations to improve education systems and furthered them at the international level. These entered national policies to a different degree. With this article, we aim to answer the question if and how OECD with its soft governance mechanisms in the context of PISA can produce convergence of national education policies in Switzerland and the US towards its recommendations. These case studies have shown that policy convergence towards OECD recommendations differs highly. The results show the whole range of policy reactions to PISA, from comprehensively reforming the education system in wellscoring Switzerland to not giving it any importance in the underperforming US. Switzerland introduced reforms in social equity as a result of PISA, while in the US, it has been far from the centre of attention in recent and on-going reforms in education policy. Switzerland did not converge towards 
the PISA recommendation of increasing school autonomy, whereas this has always characterised the US system. With regard to cooperative school structure, educational standards, as well as research and statistics, Switzerland implemented change, but the US showed a previous fit with these recommendations. Interestingly, neither countries passed reforms to promote gender equity. In teaching quality and quality assurance, they both matched OECD recommendations before PISA. Only in Switzerland can one observe reforms that can be attributed to PISA. The US already matched many OECD recommendations or had introduced them without reference to PISA. So what caused these diverging reactions? In Switzerland, federalism and the corresponding strong cantonal competences had hindered far-reaching reforms in education for decades, resulting in a high problem pressure due to a lack of intra-Swiss mobility. PISA opened a window of opportunity, as national actors referred to the study to legitimise the introduction of necessary reforms. As a result, the agreement on enhanced intercantonal cooperation with the aim of uniform educational quality led to a fundamental rearrangement of steering (Bieber, 2010b). Hence, the reform backlog was overcome. However, the impact of OECD soft governance is limited when PISA creates domestic problem pressure. This was the case in the US, where - like in other Anglo-Saxon countries (Dobbins, 2010; Knodel, 2010) — it did not trigger any change in education policy (Martens, 2010). The US PISA scores were discussed by only a few experts. The mediocre results confirmed the common estimation of the system's performance. Thus, the US engaged in independent problem-solving, which also resulted - although without transnational accords - in great consistency with the OECD recommendations. $(\leftarrow$ p. 111)

The findings show that the extent of policy convergence depends on whether OECD can trigger convergence mechanisms in the respective country if there is local problem pressure. With our two case studies, we demonstrated that reactions to PISA in terms of policy convergence differed significantly due to problem pressure and impacts of OECD mechanisms. Further comparative case studies are needed to assess the effects of international education activities on national education policies (Knodel et al., 2010). They may offer more detailed knowledge on the reasons for change and continuity in national education systems.

Tonia Bieber, University of Bremen, Collaborative Research Center 597, Transformations of the State, P.O. Box 3304 40, D - 28334 Bremen, Germany, tonia.bieber@sfb597. uni-bremen.de, www.staatlichkeit.uni-bremen.de

Kerstin Martens, University of Bremen, Sonderforschungsbereich 597 / Collaborative, Research Center 597, Transformations of the State, P.O. Box 3304 40, D - 28334 Bremen, Germany, kerstin.martens@sfb597.uni-bremen.de,www.staatlichkeit.uni-bremen.de 


\section{REFERENCES}

Aprentas (2006), Die Bildungsverfassung ist revidiert — und nun? Harmonisierung des schweizerischen Bildungssystems. Jahresbericht 2006 (Basel, APRENTAS).

Barnett, M.\& Finnemore, M. (2004), Rules for the World: International Organizations in Global Politics (Ithaca, N.Y., Cornell University Press).

Bennett, C. (1991), What is policy convergence and what causes it? British Journal of Political Science, 21, pp. 215-233.

Bieber, T. (2010a), Playing the multilevel game in education - the PISA study and the Bologna Process triggering Swiss harmonization, in: K. Martens, A. $(\leftarrow \mathbf{p . ~ 1 1 2})$ Nagel, M. Windzio \& A. Weymann (Eds), Transformation of Education Policy (Basingstoke, Palgrave).

Bieber, T. (2010b), Schweiz — PISA als Wegbereiter von Reformen, in: P. Knodel,

K. Martens, D. D. E. Olano,\& M. Popp (Eds), Das PISA-Echo: Internationale Reaktionen auf die Bildungsstudie (Frankfurt am Main, Campus).

Börzel, T.\& Risse, T. (2002), Die Wirkung internationaler Institutionen. Von der Normanerkennung zur Normeinhaltung, in: M. Jachtenfuchs \& M. Knodt (Eds) Regieren in internationalen Institutionen. Festschrift für Beate Kohler-Koch (Opladen, Leske \& Budrich).

Buschor, E., Gilomen, H. \& Mccluskey, H. (2003), PISA 2000: Synthese und Empfehlungen (Neuchâtel, Bundesamt für Statistik).

Busemeyer, M. R. (2007), Bildungspolitik in den USA. Eine historisch-institutionalistische Perspektive auf das Verhältnis von öffentlichen und privaten Bildungsinstitutionen, Zeitschrift für Sozialreform, 53, pp. 57-78.

Cibulka, J. G. (1994), Policy analysis and the study of the politics of education, Journal of Education Policy, 9, pp. 105-125.

Coleman, W. D. (2001), Agricultural policy reform and policy convergence. An actor-centered institutionalist approach, Journal of Comparative Policy Analysis: Research and Practice, 3, pp. 219-241.

Criblez, L. (2008a), Bildungsraum Schweiz: Historische Entwicklung und aktuelle Herausforderungen (Bern, Haupt Verlag).

Criblez, L. (2008b), Die neue Bildungsverfassung und die Harmonisierung des Bildungswesens, in: L. Criblez (Ed), Bildungsraum Schweiz: historische Entwicklung und aktuelle Herausforderungen (Bern, Haupt Verlag).

Criblez, L. \& Osterwalder, F. (2004), Editorial, Schweizerische Zeitschrift für Bildungswissenschaften, 26, pp. 5-9.

Dillon, S.\& Lewin, T. (2010), Education chief vies to expand U.S. role as partner on local schools, 
New York Times, 3 May, 2010.

Dobbins, M. (2010), Neuseeland - Überflieger mit Leistungsgefälle, in: P. Knodel, K. Martens, D. D. E. Olano \& M. Popp (Eds), Das PISA-Echo: Internationale Reaktionen auf die Bildungsstudie (Frankfurt am Main, Campus). Dobbins, M. \& Martens, K. (2010), A contrasting case - the U.S.A. and its weak response to internationalization processes in education policy, in: K. Martens, A. Nagel, M. Windzio \& A. Weymann (Eds), Transformation of Education Policy (Basingstoke, Palgrave).

Dobbins, M. (2008), Comparing Higher Education Policies in Central and Eastern Europe. Dissertation, Konstanz, Universität Konstanz.

Drezner, D. W. (2001), Globalization and policy convergence, International Studies Association, 3, pp. 53-78.

Eckert, M. (2009), Neue Steuerungsinstrumente in der beruflichen Benachteiligtenförderung, in: U. Lange, S. Rahn, W. Seitter \& R. Körzel (Eds), Steuerungsprobleme im Bildungswesen. Theorie und Empirie des lebenslangen Lernens (Wiesbaden, Verlag für Sozialwissenschaften).

EDK (2004), HarmoS. Zielsetzungen und Konzeption (Bern, Schweizerische Konferenz der kantonalen Erziehungsdirektoren).

EDK (2007), Interkantonale Vereinbarung über die Harmonisierung der obligatorischen Schule [HarmoS-Konkordat] vom 14. Juni 2007.

EDK (2009), HarmoS — Harmonisierung der obligatorischen Schule Schweiz (Bern, Schweizerische Konferenz der kantonalen Erziehungsdirektoren). $(\leftarrow$ p. 113)

Enders, J. (2004), Higher education, internationalisation, and the nation-state: recent developments and challenges to governance theory, Higher Education, 47, pp. 361-382.

Froschauer, U. \& Lueger, M. (2003), Das qualitative Interview zur Praxis interpretativer Analyse sozialer Systeme (Wien, WUV).

Fthenakis, W. E. (2003), Elementarpädagogik nach PISA.Wie aus Kindertagesstätten Bildungseinrichtungen werden können (Freiburg, Herder).

Furlong, P. (2005), British higher education and the Bologna Process: an interim assessment, Politics, 25, pp. 53-61.

George, A. L. \& Bennett, A. (2005), Case Studies and Theory Development in the Social Sciences (Cambridge, The MIT Press).

Goldthorpe, J. (1997), Current issues in comparative macrosociology: a debate on methodological issues, Comparative Social Research, 16, pp. 1-26.

Gonon, P. (1998), Das internationale Argument in der Bildungsreform. Die Rolle internationaler Bezüge in den bildungspolitischen Debatten zur schweizerischen Berufsbildung und zur englischen Reform der Sekundarstufe II (Bern/Berlin, Peter Lang). 
Grek, S. (2009), Governing by numbers: the PISA 'effect' in Europe, Journal of Education Policy, 24, pp. 23-37.

Gross, R. \& Gross, B. (1985), The Great School Debate (New York, Simon and Schuster).

Gürüz, K. (2003), Higher Education in the Global Knowledge Economy. Paper prepared for the Convocation, Binghamton, New York, 8 October 2003.

Haas, P. M. (1992), Introduction: epistemic communities and international policy coordination, International Organization, 46, pp. 1-35.

Hall, P. (2006), Systematic process analysis: when and how to use it, European Management Review, 3, pp. 24-31.

Hega, G. M. (2000), Federalism, subsidiarity and education policy in Switzerland, Regional and Federal Studies, 10, pp. 1-35.

Heichel, S., Holzinger, K., Sommerer, T., Liefferink, D., Pape, J.\& Veenman, S. (2008), Research design, variables and data, in: K. Holzinger, C. Knill \& B. Arts (Eds), Environmental Policy Convergence in Europe. The Impact of Inter- national Institutions and Trade (Cambridge, Cambridge University Press).

Holzinger, K. \& Knill, C. (2005), Causes and conditions of cross-national policy convergence, Journal of European Public Policy, 12, pp. 775-796.

Holzinger, K. \& Knill, C. (2008), Theoretical framework: causal factors and convergence expectations, in: K. Holzinger, C. Knill \& B. Arts (Eds), Environmental Policy Convergence in Europe. The Impact of International Institutions and Trade (Cambridge, Cambridge University Press).

Holzinger, K., Knill, C. \& Arts, B. (2008), Environmental Policy Convergence in Europe: The Impact of International Institutions and Trade (Cambridge, Cambridge University Press).

Jakobi, A. P., Martens, K.\& Wolf, K. D. (2009), Education in Political Science - Discovering a Neglected Field (London/New York, Routledge).

Knill, C. \& Lehmkuhl, D. (1999), How Europe matters: different mechanisms of Europeanization, European Integration online Papers, 3, pp. 1-19.

Knill, C. \& Lenschow, A. (2005), Coercion, competition and communication. Different approaches of European governance and their impact on national institutions, Journal of Common Market Studies, 43, pp. 581-604. ( $\leftarrow$ p. 114)

Knill, C. \& Tosun, J. (2008), Policy making, in: D. Caramani (Ed) Comparative Politics (Oxford, Oxford University Press).

Knill, C., Tosun, J.\& Bauer, M. W. (2009), Neglected faces of Europeanization: the differential impact of the EU on the dismantling and expansion of domes- tic policies, Public Administration, 87, pp. 519-537. 
Knodel, P. (2010), England - PISA und die 'pick and choose'-Strategie, in: P. Knodel, K. Martens, D. D. E Olano \& M. Popp (Eds), Das PISA-Echo: Internationale Reaktionen auf die Bildungsstudie (Frankfurt am Main, Campus).

Knodel, P., Martens, K., Olano, D. D. E. \& M. Popp (2010), Das PISA-Echo: Internationale Reaktionen auf die Bildungsstudie (Frankfurt am Main, Campus).

Kohlrausch, B.\& Leuze, K. (2007), The impact of marketization on the perception of education as public or private good, in: K. Martens, A. Rusconi \& K. Leuze (Eds), New Arenas of Education Governance - The Impact of International Organizations and Markets on Educational Policy Making (Basingstoke, Palgrave).

Lingard, B. \& Grek, S. (2007), The OECD, Indicators and PISA: an exploration of events and theoretical perspectives (Edinburgh, ESRC/ESF Research Project).

Mahon, R.\& McBride, S. (2008), The OECD and Transnational Governance (Van- couver, University of British Columbia Press).

Maradan, O. \& Mangold, M. (2005), Bildungsstandards in der Schweiz. Das Projekt HarmoS, PH Akzente, 2, pp. 3-7.

Martens, K. (2007), How to become an influential actor - the 'Comparative Turn' in OECD education policy, in: K. Martens, A. Rusconi \& K. Leuze (Eds), New Arenas of Education Governance - The Impact of International Organizations and Markets on Educational Policy Making (Basingstoke, Palgrave).

Martens, K. (2010), USA — Wie man PISA auch ignorieren kann, in: P. Knodel,

K. Martens, D. D. E. Olano \& M. Popp (Eds), Das PISA-Echo: Internationale Reaktionen auf die Bildungsstudie (Frankfurt am Main, Campus).

Martens, K. \& Jakobi, A. P. (2010), Introduction. The OECD as an actor in international politics, in: K. Martens \& A.P. Jakobi (Eds), Mechanisms of OECD Governance. International Incentives for National Policy-Making? (Oxford, Oxford University Press).

Martens, K.\& Niemann, D. (2010), Governance by Comparison. How Ratings \& Rankings Can Impact National Policy Making in Education, TranState Working Papers, Collaborative Research Center 597, University of Bremen.

Martens, K. \& Wolf, K. D. (2006), Paradoxien der neuen Staatsräson: die Internationalisierung der Bildungspolitik in der EU und der OECD, Zeitschrift für internationale Beziehungen, 13, pp. 145176.

McGuinn, P. (2006), Swing issues and policy regimes: federal education policy and the politics of policy change, Journal of Policy History, 18, pp. 205-240.

Meseguer Yebra, C. (2003), Learning and Economic Policy Choices: A Bayesian Approach (Florence, European Forum Working Paper Series, European University Institute, no 5). 
Meyer, J. W. (2005), Weltkultur. Wie die westlichen Prinzipien die Welt durchdringen (Frankfurt am Main, Suhrkamp Verlag).

Meyer-Hesemann, W. (2010), Lernen von der Schweiz. Die deutschen Bundesländer sollten sich jetzt auf ein zweigliedriges Schulsystem verständigen, DIE ZEIT (5), 28 January 2010. ( $\leftarrow$ p. 115)

Morgan, C. (2009), Transnational Governance. The Case of the OECD PISA, Paper presented at the Annual Conference of the Canadian Political Science Association, Ottawa, 27 May 2009. www.cpsa-acsp.ca/papers-2009/Morgan.pdf. 30 September 2010.

Münch, R. (2009), Globale Eliten, lokale Autoritäten: Bildung und Wissenschaft unter dem Regime von PISA, McKinsey \& Co (Frankfurt am Main, Suhrkamp).

Nagel, A., Martens, K. \& Windzio, M. (2010), Introduction - education policy in transformation, in: K. Martens, A. Nagel, M. Windzio \& A. Weymann (Eds), Transformation of Education Policy (Basingstoke, Palgrave).

National Commission on Excellence in Education (1983), A Nation at Risk: Imperatives for Educational Reforms. www2.ed.gov/pubs/NatAtRisk/index.html. OECD (2002) Lesen kann die Welt verändern: Leistung und Engagement im Ländervergleich (Paris, OECD).

OECD (2004a), Messages from PISA 2000.The Final Summary Report from the PISA 2000 Survey (Paris, OECD).

OECD (2004b), What Makes School Systems Perform. Seeing School Systems through the Prism of PISA (Paris, OECD).

OECD (2007), PISA 2006. Schulleistungen im internationalen Vergleich. Naturwissenschaftliche Kompetenzen für die Welt von morgen (Bielefeld, W. Bertelsmann Verlag).

OECD (2009), Education Today. The OECD Perspective (Paris, OECD). OECD (2010) Education at a Glance. OECD Indicators (Paris, OECD).

Parreira Do Amaral, M. (2006), The Influence of Transnational Organizations on National Education Systems (Frankfurt am Main, Peter Lang).

Rinne, R., Hokka, S. \& Kallo, J. (2004), Too eager to comply? European Educational Research Journal, 3, pp. 454-485.

Rose, R. (1991), What is lesson-drawing? Journal of Public Policy, 11, pp. 3-30.

Scharpf, F. W. (1988), The joint decision trap. Lessons from German federalism and European integration, Public Administration, 66, pp. 239-278.

Schweizerische Koordinationsstelle Für Bildungsforschung (SKBF) (2010) Bildungsbericht Schweiz 2010 (Aarau, SKBF).

Sommerer, T., Holzinger, K. \& Knill, C. (2008), The pair approach: what causes convergence of environmental policies? in: K. Holzinger, C. Knill \& B. Arts (Eds), Environmental Policy Convergence in Europe: The Impact of International Institutions and Trade (Cambridge, 
Cambridge University Press).

Tews, K., Busch, P. \& Jörgens, H. (2003), The diffusion of new environmental policy instruments, European Journal of Political Research, 42, pp. 569-600.

Walkenhorst, H. (2008), Explaining change in EU education policy, Journal of European Public Policy, 15, pp. 567-587.

Wolter, S. C. \& Vellacott, M. C. (2002), Sibling Rivalry: A Look at Switzerland with PISA Data. Discussion Paper No. 594 (Bonn, Forschungsinstitut zur Zukunft der Arbeit).

Zahner Rossier, C. (2005), PISA 2003: Kompetenzen für die Zukunft II (Neuchâtel/ Bern, Bundesamt für Statistik).

Zahner, C., Moser, U., Brühwiler, C., Vellacott, M. C., Huber, M., Malti, T., Ramseier, E., Wolter, S. C. \& Zutavern, M. (2002), Für das Leben gerüstet? Die Grundkompetenzen der Jugendlichen - Nationaler Bericht der Erhebung PISA 2000 (Neûchatel, Bern, Bundesamt für Statistik/Schweizerische Kon- ferenz der kantonalen Erziehungsdirektoren). ( $\leftarrow$ p. 116) 